\title{
The Joola civilization and the management of mangroves in Lower Casamance, Senegal
}

Civilisation diola et gestion de la mangrove en Basse Casamance, Sénégal

Claudette Soumbane Diatta, Malick Diouf, Amadou Abdoul Sow and Charlotte Karibuhoye

\section{(2) OpenEdition}

\section{Journals}

Electronic version

URL: http://journals.openedition.org/ethnoecologie/5855

DOI: 10.4000/ethnoecologie.5855

ISSN: 2267-2419

Publisher

Laboratoire Eco-anthropologie et Ethnobiologie

\section{Electronic reference}

Claudette Soumbane Diatta, Malick Diouf, Amadou Abdoul Sow and Charlotte Karibuhoye, « The Joola civilization and the management of mangroves in Lower Casamance, Senegal », Revue d'ethnoécologie [Online], 17 | 2020, Online since 30 June 2020, connection on 03 July 2020. URL : http:// journals.openedition.org/ethnoecologie/5855; DOI : https://doi.org/10.4000/ethnoecologie.5855

This text was automatically generated on 3 July 2020.

\section{cc) (†)}

Revue d'ethnoécologie est mis à disposition selon les termes de la licence Creative Commons Attribution - Pas d'Utilisation Commerciale - Pas de Modification 4.0 International. 


\title{
The Joola civilization and the management of mangroves in Lower Casamance, Senegal
}

\author{
Civilisation diola et gestion de la mangrove en Basse Casamance, Sénégal
}

Claudette Soumbane Diatta, Malick Diouf, Amadou Abdoul Sow and Charlotte Karibuhoye

\section{Introduction}

1 Mangrove ecosystems are unique and complex natural environments that consist mainly of woody plants and are essential for the survival and development of local populations in the Lower Casamance. They are highly productive and provide multiple goods and services (Cormier-Salem 1999, Bassene 2016). Mangrove ecosystems also serve as shelters and nurseries for many juvenile fish and shellfish (Ibid.). For people living in coastal areas, particularly in Lower Casamance, the mangrove is a precious economic and cultural resource (Marut 2010, Diatta 2012, Badji 2015, Ka et al. s.d.).

The vegetation represented in this ecosystem is composed of various mangrove species including Rhizophora and Avicennia, which belong to the families Rhizophoraceae and Avicenniaceae, respectively. Rhizophora species are found along streams while those of Avicennia are found in mudflats. The distribution of these species influenced by salinity. Species in the genus Avicennia are able to tolerate higher salinity than species in the Rhizophora genus due to an adaptation that allows leaves and roots in the former to exude salt (Laffargue 2010). Unfortunately, mangroves are being degraded worldwide as a result of human exploitation and climate change (FAO 2007, IMAO 2009). In 2008, the FAO estimated that 3.6 million hectares of mangrove forest has been lost since 1980 . In Senegal, the total area of mangrove forest in 1980 was $1,690 \mathrm{~km}^{2}$ of which almost $50 \%$ is located in the Casamance, and which declined by $32 \%$, to an area of $1,150 \mathrm{~km}^{2}$, by 2005 (Borrini-Feyerabend et al. 2009). A loss of about 2,400 ha of mangrove was recorded in the period 1970 to 1973 (HARZA 1984). In the Lower Casamance, Marius 
(1985) reported that since $1969,70 \%$ to $80 \%$ of Rhizophora have disappeared: due to decreases in rainfall, increases in salinity, acidification of the land, excessive cutting. However, after a period of stability following a return of rainfall in the 1980s, the mangrove still experienced a pronounced decline. The Regional Planning Commission estimated that the total mangrove cover was 70,000 ha in the 1990 in Lower Casamance (Badiane 2012). In addition, the mangrove has experienced a spectacular regression during dry periods, causing increasing salinization of the estuary and groundwater (Cormier-Salem 1992, Marut 2010). Today, even if we observe a regeneration of mangrove following reforestation (Cormier-Salem et al. 2015, Solly 2018), there are still pockets of degradation. This mangrove regeneration accounts for about $69 \%$ of the area lost between 1972 and 2000 in the village of Thiobon (Solly et al. 2018). The combined impacts of increased soil salinity, acidification, and damage to mangrove forests has led to a loss of arable land in rice fields in Lower Casamance (Laffargue 2010).

3 In addition to the effects of climate change, agricultural developments the increase in the urban population, and various waves of migration have caused damage to mangroves (Bassene 2016), which is most evident at the level of the villages of Tobor and Niaguis in the Lower Casamance region. Companies such as ILACO in the 1970s and the construction of the anti-salt dams such as those of Guidel (zone of Niaguis) and Affinian, in the Tobor area in the 1980-80s, have damaged thousands of hectares of mangrove forests. Moreover, the arrival of displaced populations following the armed conflict between the Mouvement des Forces Democratiques de Casamance (MFDC) and the Senegalese government since 1982 has also contributed to the degradation of the mangrove ecosystem. Most of these displaced populations use mangrove resources such as shellfish, fish, and timber to survive. This situation led to a net loss of mangrove forest from 1957 to 2010 , from $54.12 \mathrm{~km}^{2}$ to $44.38 \mathrm{~km}^{2}$, a $9.7 \%$ loss of its area (Ibid). Thus, in the Casamance estuary, and more particularly in Tobor, where mangroves are a source of food and income, there is an important disappearance of this ecosystem in the northwest and essentially around the village which saw it almost disappear between 1972 and 1986 (Cormier-Salem et al. 2015). The consequences of mangrove degradation are the loss of biodiversity and people's livelihoods of populations for whom fishing and oyster harvesting have provided dietary protein for centuries and an important source of family income (Laffargue 2010).

4 Thanks to the traditional religion animism Joola concepts such as the sacredness of space have contributed significantly to the preservation of certain parts of the mangrove. These sacred natural sites in general and in particular those located in the mangrove areas thus show a better state of conservation compared to spaces that do not benefit from this status (Badiane 2012, Diatta et al. 2017). Thus, despite the apparent degradation of the mangrove, some areas including sacred sites have been preserved even though the primary goal of many of these practices was not conservation. In addition, these sacred sites represent for the divine vodun populations concerned "places of communion, transmission of collective memory and recognition of identity" (Juhé-Beaulaton et al. 2002 et 2010). Therefore, the conservation of the biological diversity is not an objective. Dugast (2002) argues that for the of Guyana's Wayampi society, the conservation of mangroves is more a consequence of their cosmology.

5 Endogenous secular practices have preserved these sacred sites which are habitats with a rich biodiversity. In this regard, Gadou (2003) notes that "it is thanks to these rules that are a function of the predominant type of activity, of the ecological environment, 
or of the spiritual relations maintained with the super-natural powers, that the environment in Africa has most often preserved degradation". In the same vein, UICN/ CEESP (2010) note that many local communities around the world have contributed to the preservation of their natural resources according to rules passed down from generation to generation. In the context of the Joola, this practice is known by the local name of hutongh or hubene that has ensured the sustainable use of the mangrove ecosystem. The lack of scientific data on mangrove management and conservation practices on the Joola subject is sparse which, is the main motivating factor of this study.

6 The Joola are a West African people whose living animist traditions still govern social life. The Joola culture is characterized by the sacred respect of ancestral values and belief that nature is an integral part of the society. These elements represent values that go beyond simple conservation actions. The Joolas occupy a territory that extends over the Gambia, in Casamance, located in Southern Senegal, and Guinea-Bissau. It is the main ethnic group of Lower Casamance accounting for $57.8 \%$ of the population of the region according to the last census of the population of Senegal in 2013. Alongside Joolas, cohabit other ethnic groups, including the Mandingos (11.10\%), the Pulaars group (10.5\%), the Wolofs (3.9\%), the Manjacks (3.5\%), the Ballantes (2.9\%), the Serer (2.70\%) and Mancagnes (2.4\%) (ANSD 2015).

\section{Objectives of the study}

7 The main concern of this study is to understand the impacts of Joola customs and practices on mangrove conservation. This article highlights the importance of culture and traditions that have been perpetuated by people for ages. It also reviews traditional methods of in situ conservation that have helped preserve some mangrove areas and their associated biodiversity.

\section{Field of study}

8 The Lower Casamance, the site of this study, is located in Southern Senegal between Gambia to the North, Guinea Bissau to the South, the Atlantic Ocean to the West and the region of Sedhiou to the East. It corresponds to the administrative region of Ziguinchor and is located between $12^{\circ} 34^{\prime} 59^{\prime \prime} \mathrm{N}$ latitude and $16^{\circ} 16^{\prime} 18^{\prime}$ " $\mathrm{W}$ longitude.

9 The Lower Casamance region benefits from a humid climate characterized by two very contrasting seasons: one dry and the other rainy. It belongs to the South-Sudan coastal climate domain (Sagna 2007) with a variant in the coastal area. This climate is marked by an average rainfall of $1000 \mathrm{~mm}$, a high humidity exceeding $80 \%$ throughout the year, and rather high temperatures depending on the season. The average annual temperature (TM) in Ziguinchor is $27.8^{\circ} \mathrm{C}$. The trade winds that blow from November to February and the monsoon from April to October are dominant weather features in the region.

10 The actual study was carried out in the coastal areas of Blouf, Bandial, Kassa, BlissKarone, Bliss-Kassa and Fogni Diabang. It involved 10 communes in 27 villages (Figure 1). These localities are populated mainly by the Joola, but which differ in their language (Cormier-Salem 1992). Indeed, the Joola are split into several subgroups identified by a 
spoken, a different denomination and location. The Blouf, Bandial and Kassa subgroups bear the same name as the region they occupy. The Karone and Kassa subgroups occupy the regions of Bliss-Karone, Bliss-Kassa and Fogni Diabang.

11 The Joolas of Blouf occupy the northern part of the region. It corresponds administratively to the department of Bignona and the district of Tendouck. The traditional religion, which includes fetishism (Journet-Diallo 2007, Bodian 2018), has almost disappeared in some villages. While the population is predominantly Muslim, here and there fetishes are present and with various functions or processions of women led by priestesses in time of misfortune. Indeed, authors such as Pélissier (1966) and Thomas (1958/59) who have largely described the cultural peculiarities of the Joola distinguish within this acephalous ethnicity, three main subgroups: the Joola South animists of the Kassa, the North Muslim Joola of Blouf and the Mandingo Joola of Fogny. Today, this typology is recognized despite significant clarifications made by the authors (Marzouk-Schmitz 1993, Diedhiou 2011, Journet-Diallo 2007)

The Kassa subgroup of Joolas occupy the department of Oussouye and are considered the oldest installation Joola community in Lower Casamance (Pélissier 1966). The particularity of this region lies in its anchorage to ancestral customs where populations have remained faithful to custom and ancestral practices. These traditions are still practiced despite the adoption of Islam and Christianity. Kassa Joolas are also found on the north bank of the estuary of the Casamance River in the villages Haer, Hitou, Niomoune and Diogué and Bakassouk. Joolas Karone are present in Kafountine commune and live on the mainland (Fogni Diabang) and on the insular part. They are still very attached to traditional customs. The Bandial are located on the left bank of the Casamance River. They occupy the municipality of Enampore, which is part of the Niassia district.

Figure 1: Location of the study area and spatial distribution of Joola subgroups

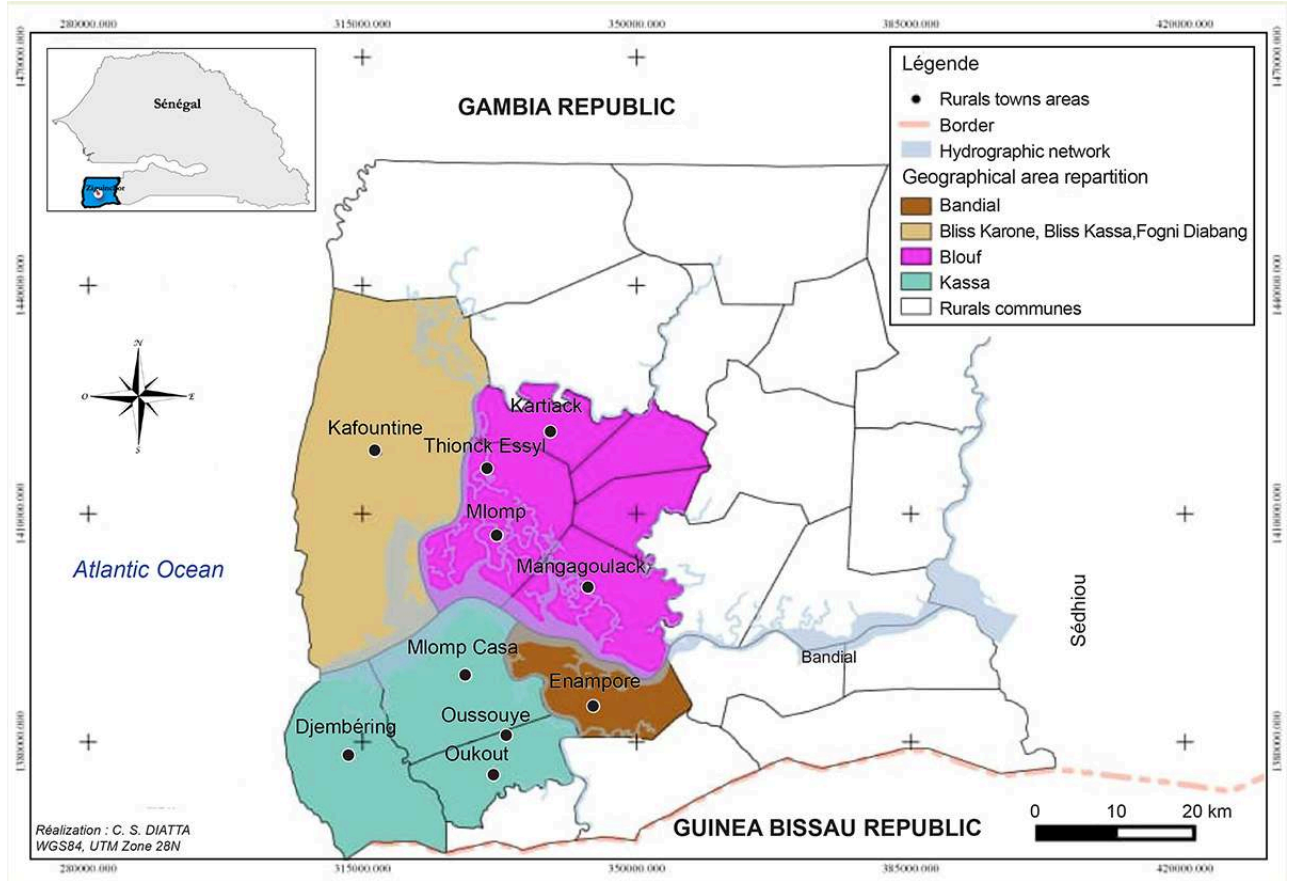



this formerly lush forest formation experienced a significant regression in its area following the rainfall deficits of the 1970s (Laffargue 2010, Cormier-Salem et al. 2015). Until 1970, the average annual rainfall reached $1506 \mathrm{~mm}$ (data from 1918 to 1970).

mangrove vegetation of Lower Casamance is composed of various mangrove species, the most important of which are Rhizophora racemosa and Avicennia nitida, known in joola as oumack and oubedj. They are accompanied by Laguncularia racemosa, Conocarpus erectus, Sesuvium portulacastrum and Philoxerus vermicularis (Vieillefon 1975). The Rhizophora species is located at the edge of the creeks and constitute the pioneer vegetation of the areas where the mud is the least consolidated. Avicennia species develop in less humid and sandy soils and are located the Rhizophoraceae. Laguncularia racemosa is found on newly formed muddy banks. Sesuvium portulacastrum and Philoxerus vermicularis, halophile crassulescent plants, often accompany Avicennia nitida on the edge of the tanne (Vieillefon 1975). Conocarpus erectus (gray mangrove) occurs on the edges of the mangrove mainland in compact sandy-clayey soils that are regularly drained and have low salt content.

\section{Methodology}

After a bibliographic research on the Joola people and their practices, a qualitative survey was conducted among local populations to obtain information on their knowledge, skills, habits and customs. Our methodological approach was based on the principles, methods and tools of the participatory approach (FAO 1995). The qualitative method was favored because the objectives of the study and the nature of the data sought call for a greater emphasis on these socio-cultural aspects. The survey was carried out on $1 / 5$ of the households in the villages selected using a questionnaire that was particularly focused on local mangrove practices and management methods. Various forms of sampling were combined: by quota (total population size) and snowball (resource persons). The quota method was used for the household survey, which included chiefs. Households were chosen at random, but making sure to have a good coverage of the study area and taking into account the indications given by the populations. The combination of the snowball method has enriched our sample. The remarkable people by their knowledge of the customs and traditions were indicated by the populations. In total, 376 people were interviewed (Table 1). This proportion was determined from data from the 2002 General Population and Housing Census which at the time of the study was the only reliable statistical data available. At the same time, 27 resource persons, including the customary custodians, sages and fetish priests, were interviewed.

Interviews and observations in the field allowed us to gather information about people's practices, the material and symbolic world in which they evolve. Moreover, they allowed us to understand first-hand the socio-cultural, environmental and economic realities of the field of study. The questions asked related to the customs, practices traditional mangrove management systems and local knowledge. 
Table 1: Number of respondents in each rural communes in the study area

\begin{tabular}{c|c|c}
\hline Rural communes & Percentage (\%) of households surveyed & Number of participants \\
\hline Kafountine & 18 & 67 \\
\hline Kartiack & 7 & 26 \\
\hline Mangagoulack & 11 & 40 \\
\hline Mlomp (Blouf) & 2 & 10 \\
\hline Thionck-Essyl & 8 & 29 \\
\hline Djembering & 15 & 57 \\
\hline Mlomp (Kassa) & 15 & 57 \\
\hline Oukout & 12 & 44 \\
\hline Oussouye & 5 & 18 \\
\hline Enampore & 7 & 28 \\
\hline Total & 100 & 376
\end{tabular}

SOURCE: DIATTA 2018

\section{Results and discussion}

The mangrove is the amphibian forest that stretches all along the Casamance River and its tributaries. It is classified as one of the most complex ecosystems because of its structural and functional diversity.

In Lower Casamance the mangrove ecosystem is associated with the traditional and cultural activities of the Joola population. In some villages such as Thionck Essyl, Mlomp, the branches of Avicennia nitida are used to make the encouraged stick which is used as weapons for the youngest initiates in the sacred wood. Mangrove areas are declared sacred and constitute an important part of the identity of the people. This is confirmed by Wild and Mcleod (2008) who note that these sacred spaces represent for the local populations "the cornerstone of the vision of the world, their cultures and philosophies".

\section{Traditional mangrove management systems and associated resources}

19 The mangroves of Lower Casamance, as in most regions of the Southern rivers, are governed by customary legislation that allows collective management by village communities (Cormier-Salem 1992). Other marine resources, as well as cultivated land, and bush among others are also subject to restrictions underpinned by taboos, prohibitions, the totemic system, mystical deterrence and sanctions.

The socio-economic and cultural importance of some mangrove resources such as shells, totemic species, ritual sites, shelters of totems and totem shelters explains the development of management strategies deployed for generations by the Joola.

\section{Taboos imposed on mangrove resources}

The Joola society is based on a discipline made of prohibitions and obligations (Trinquaz 1981). Despite its egalitarian and individualistic character, "the traditional Joola society is not anarchic; a rich range of customs, some of which are authentic village institutions, constitute a social glue that ensures the group's cohesion by shaping the Joola man according to the norms of the tradition and imposing on him a 
certain number of disciplines and rules of life in the service of the common good" (Pélissier 1966). The rules (taboo and forbidden) and local customs ensured the conservation of a number of culturally important resources. The mangrove is part of this set of restrictions. Access to taboo places, consumption of oyster in some of these sites and cutting of wood are prohibited.

The mangrove ecosystem provides many goods and services. It filters the waters flowing from the land to the sea and retains many sedimentary pollutants, both organic and inorganic. It provides a habitat for many juvenile fish and shellfish that populate both reef and ocean environments. In order to avoid practices that are destructive to mangroves, taboos are instituted on certain areas of ecological importance to fisheries resources, including shellfish and finfish. The taboo is something that cannot be touched as it is vested with a sacred power deemed dangerous or impure. It's justified by a principle tending towards the possibility of a harmful consequence (Artaud 2014). A taboo status is a decisive factor in influencing the behavior of populations with regard to the use of the resource in question. Taboo status has served to protect the bolong and its resources. Taboo status is indicated a visible sign such as a piece of red cloth, ronier palm or Borassus aethiopium, etc. (photo 1).

Photo 1 : Guardian Fetish of Mitij bolong

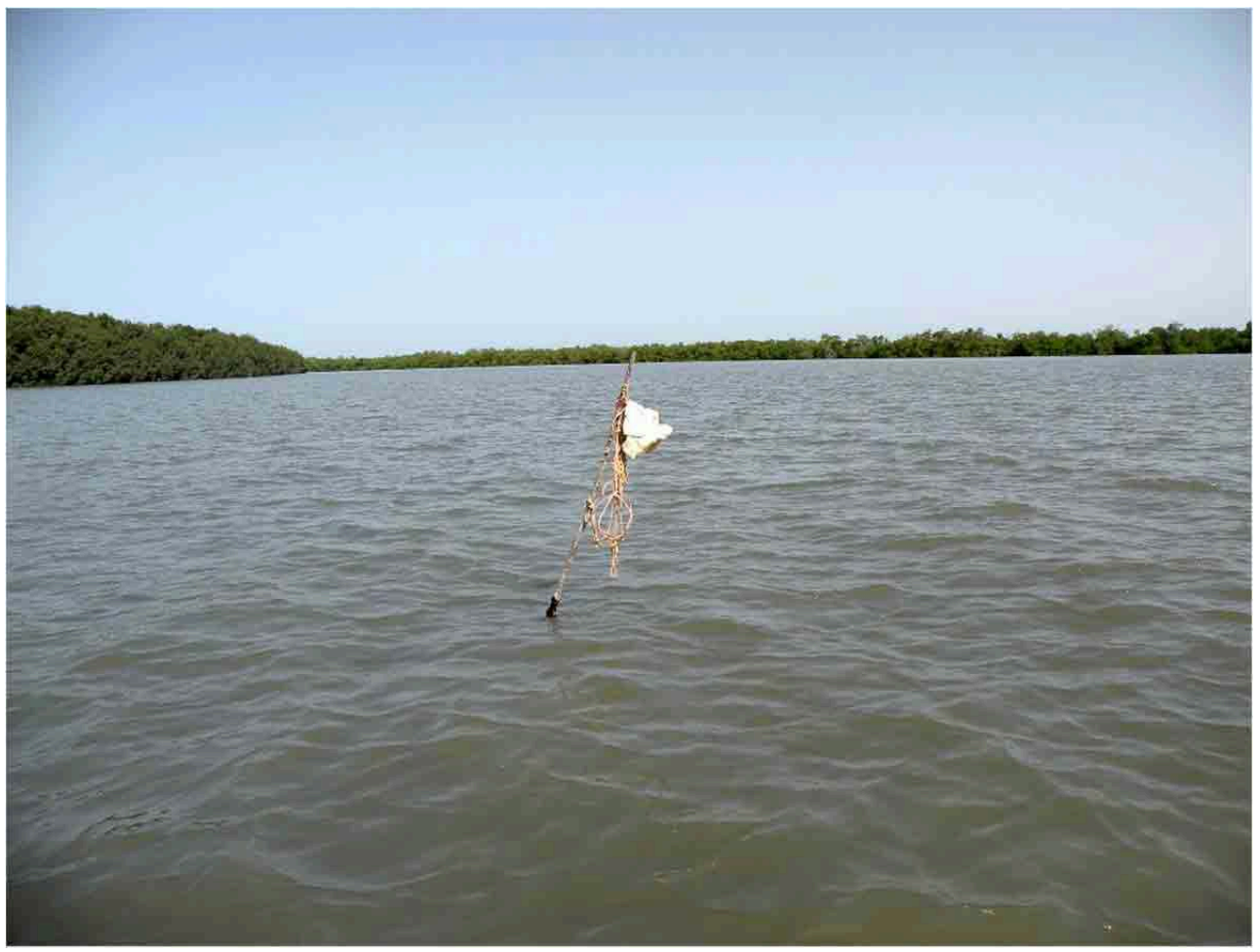

Source : Diatta 2015

To preserve the ecological functions of spawning zone, nursery and ecological niches of the mangrove and fishery resources the taboo is instituted. In the study area, only in the area of Blouf precisely in the communes of Mangagoulack and Thionck-Essyl the bolongs are deemed taboo because they constitute important ecological breeding and nursery areas). In the commune of Thionck-Essyl in the bolong of Kadiaka are forbidden. The bolong of Mitij, and in Mangagoulack, in the bolongs of Kiling-Kiling and Mitij, extractive activities also prohibited. Nevertheless, regulated fisheries have been carried out in the Mitij in the ICCA (Indigenous and Community Heritage Area) 
since 2010. It is officially recognized by the country's jurisdiction as Kawawana ICCA. After its creation, other ICCAs followed. Today there are two official ICCAs in Lower Casamance region ("Kawawana" from Mangagoulack, "Kapak Olal" from Mlomp) and one undergoing formalization ("Bourongh Olal" from Bliss Kassa). "Bournong Olal" still does not have ICCA status due to an entry error on the area ofthe space to be protected. Indeed, the recognition of the knowledge and traditions of indigenous communities in accordance with the spirit of Article $8 \mathrm{j}$ has favored the creation of community protected areas, thus encouraging the involvement of grassroots communities. However, like the protected areas of Senegal, today there are crucial and imperative questions regarding their management. Limiting factors remain good governance, shared governance (Cormier-Salem et al. 2015).

The oyster (Crassostrea gasar) and the ark (Senilia senilis) respectively soole and equékob or equindabor in joola are of great socioeconomic and cultural importance to the populations. Oysters hanging on the roots of Rhizophora are harvested using rudimentary instruments composed of cutter, ax, stick, ranger baskets, etc. The arches are harvested by hand or with other instruments such as rake, skimmer, etc.

In some Joola villages, the ark represents a totemic species. This is the case of the village of Saloulou where they represent the totem of the Diassy family. The totem (ewuum in Joola) is a double of human being. They are intimately linked so that everything that affects the totem is reflected in its double human. Therefore, it is well protected and it is forbidden to kill or consume it. However, the species as such is not subject to these restrictions. Indeed, the animal of the same species as the totem can be consumed. For example, "those who eat mullet fish as ewuum and eat it. Because under the appearance of the mullet, the ewuum is not an ordinary fish and knows how to hide itself" (Journet-Diallo 1998).

Arches and oysters bring in significant income. Operators after a collection campaign can exceed 500,000 CFA francs or 867,03 US dollars (Figure 2). Their exploitation is subject to a strict regulation which imposes the suspension of the activity of collection most often with the approach of the wintering towards the end of June until the beginning of January. To enforce the rules, these resources are temporarily invested with sacred power. This defense commonly known as hubène or hutongh, aims to guarantee that oysters and arches reach maturity before exploitation. In addition, it prevents over-exploitation and ensures equal access for all members of the community. 
Figure 2: Revenues from the sale of mangrove products (oysters and arches)

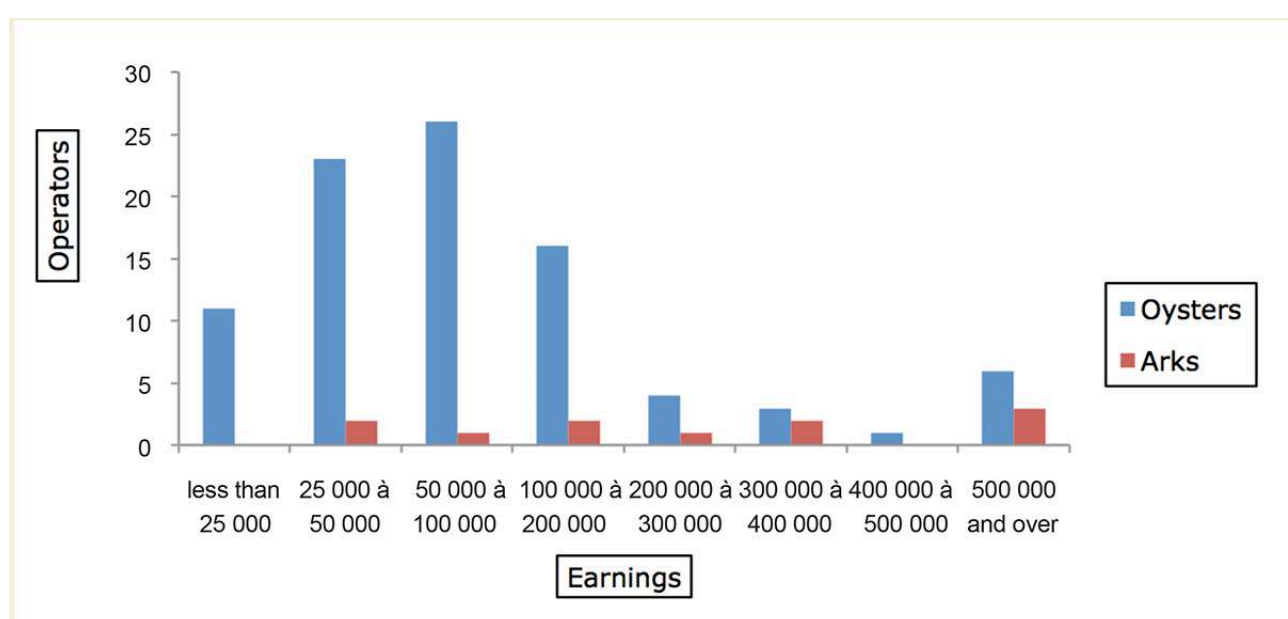

Source: Surveys, 2015

These conservation practices are also observed in many populations living near mangrove areas of West African countries. Cormier-Salem (1999) points out the existence of such practices in "West African Societies and Mangroves of the Rivers of the South." According to this author, "prohibitions prevent the overexploitation of natural resources: some fishing or gathering areas oysters are set aside all or part of the year, and oysters are only harvested in the dry season between September and June. "Generally the harvesting activity is interrupted during the rainy season, when the rice is cultivated. The reason is that overwintering would correspond to the breeding period of oysters and arches (Dioh 1976, Seck 1986, Cormier-Salem 1992). This is why biological rest is observed during this period (Badji 2015, Diatta 2018, Ka et al. s.d.). To enforce this downtime, a taboo is decreed. The duration of suspension varies between six and eight months, according to the villages. For example in Tiobon, the exploitation is stopped for a period of eight months (June to January), while in ThionckEssyl it is six (July to December). In the Mangagoulack community area, the ICCA rules are applied. The oyster harvest is stopped from June 1 until the beginning of February. It only starts on February 15th and stops on May 31st. In Karone precisely at Hillol, women rarely observe biological rest. Shellfish harvesting is interrupted when the resource begins to become scarce or the size of the individuals is small. The stop lasts a few months or even a few years.

There is also a custom that considers that when you have sown rice, you must not cross the rice fields with oysters because the seeds will not be good. "This confirms the work of Cormier-Salem (1992), who notes that it is forbidden to cut the oysters or consume them from the first rains. This custom, inherited from the ancestors, is clearly affirmed in the villages of Badiat, Brin, Batinière, Eloubaline, Mangagoulak, Elana, Niomoune (Cormier-Salem 1992). It was believed that harvesting them in winter could cause misery in the village or a bad harvest. In fact, as soon as the rice is thrown until it matures, picking of oysters is not allowed. For the mangrove, it was also thought that bringing the wood back to the village by bundle of wood from the beginning of transplanting was likely to lead to a misfortune that would force people to stop the rice works. It was recommended to cut it into small pieces and put it in a basket when bringing it to the village. These beliefs seem to show both the importance of rice 
cultivation in Joola and the importance of the mangrove and these resources. Thus, even if, in terms of conservation, these beliefs are beneficial, they now tend to disappear.

The Joola populations of Lower Casamance have mangrove and its resources management practices ranging from forbidden cutting to the consumption of seafood, oyster in particular, in the sacred spaces. Totem shelters, places of ritual are the different types of sites encountered in the study area. These taboo sites located in the mangrove are generally forbidden to any form of exploitation. In some, the mangrove wood is only reserved for the great initiation ceremony of men and serves as fuel in the sacred wood. At the level of the ritual sites, the consumption of oysters collected in these places is forbidden for women of Bliss-Kassa (Diatta et al. 2017). These rules can ensure the long-term conservation of the resource. Moreover, it is admitted by the populations that the oysters of the taboo sites are by far larger and the vegetation better preserved. This fact could be verified by the observations at the time of the study.

It should be noted that Joola beliefs and perceptions have had a positive impact on the protection of the environment in Lower Casamance. This idea is further developed by Dupire (1991), who emphasizes that the Serer ndut have through the worship given to the genies of the places, to the forces of nature, to the spirits of the animal species and ancestors, have contributed to preserve the environment natural. "From the ritual control of nature, one passes imperceptibly to one's protection" (Ibid). Similar examples are noted in the Sine-Saloum Niominka Serer (Cisse et al. 2004) as well as in the Joal-Fadiouth populations (Sene et al. 2013).

In the Joola environment, taboos constitute the basis of the management of natural resources. It is dangerous to break them, as this can lead to serious consequences for the guilty party. Illness or death are consequences of non-compliance with the prohibitions. In this way, they contribute to the stability of the natural environment and the maintenance of order established by the community. According to Artaud (2014), the taboo is a determining principle in the process of species renewal. Thus, even though there is a trend towards uncontrolled exploitation of natural resources, the traditional rules still in force exclude abusive extraction. For fishing in the mangrove for example, apart from the prohibitions to exploit in sacred sites, there are rules conditioning the access to the resource in certain localities of the Karone. For example, in the village of Couba, these rules include the imposition of a tax or offering of 5 liters palm wine at the "boekin" altar for foreign farmers. Note that the Boekin (plural ukiin) represents deities that allow reaching Ata Emit that is to say God. Ukiin are hierarchical in individual, lineage or community. Thus, foreign fishermen who do not reside in Couba are required to pay a sum of 5,000 CFA francs or 8.64 US dollars to fish in the bolongs of the village. Similar measures are also applied in neighboring villages including Boune and Boco. Badji (2015) reveals that women (except those from the village, but married in other localities, or parents from the village) who are not from these villages are required to give at the end of the campaign collection, a basin of dry arches. These rules of use contribute to the control of resources and also make it possible to preserve them. 


\section{Marine sacred sites, an important means of security for the mangrove and associated resources}

The mangrove areas are home to many sacred natural sites that have long been maintained and managed by local communities, with methods and tools generated by the local culture. These sacred sites are of different types. There are sacred sites dedicated to cultural practices including those related to the initiation of bukut is a rite of passage male also referred to as foutamp (in Fogni), bugut or geurur in Thionck-Essyl, Affignam, Bandial etc. This rite of passage allows the Joola man to discover the secrets of traditional life, the mysteries, the local cosmogony, etc. Its accomplishment allows the young Joola to enter the adult class. Other sites that exist are religious sites: places of religious rituals, sites for the conservation of biological diversity and shelters of geniuses. The inventory carried out in the localities where we conducted our study gave a total of 109 sites located at the different sills of the Casamance River, each fulfilling a specific function. Totems are present in $81 \%$ of the listed sites, making a total of 89 sites. The remaining $19 \%$ are shared between the sites serving as a cockpit for geniuses or jinn, those used for initiatory rites and finally those housing a fetish (Figure 3).

Figure 3: Categories of marine sacred sites encountered

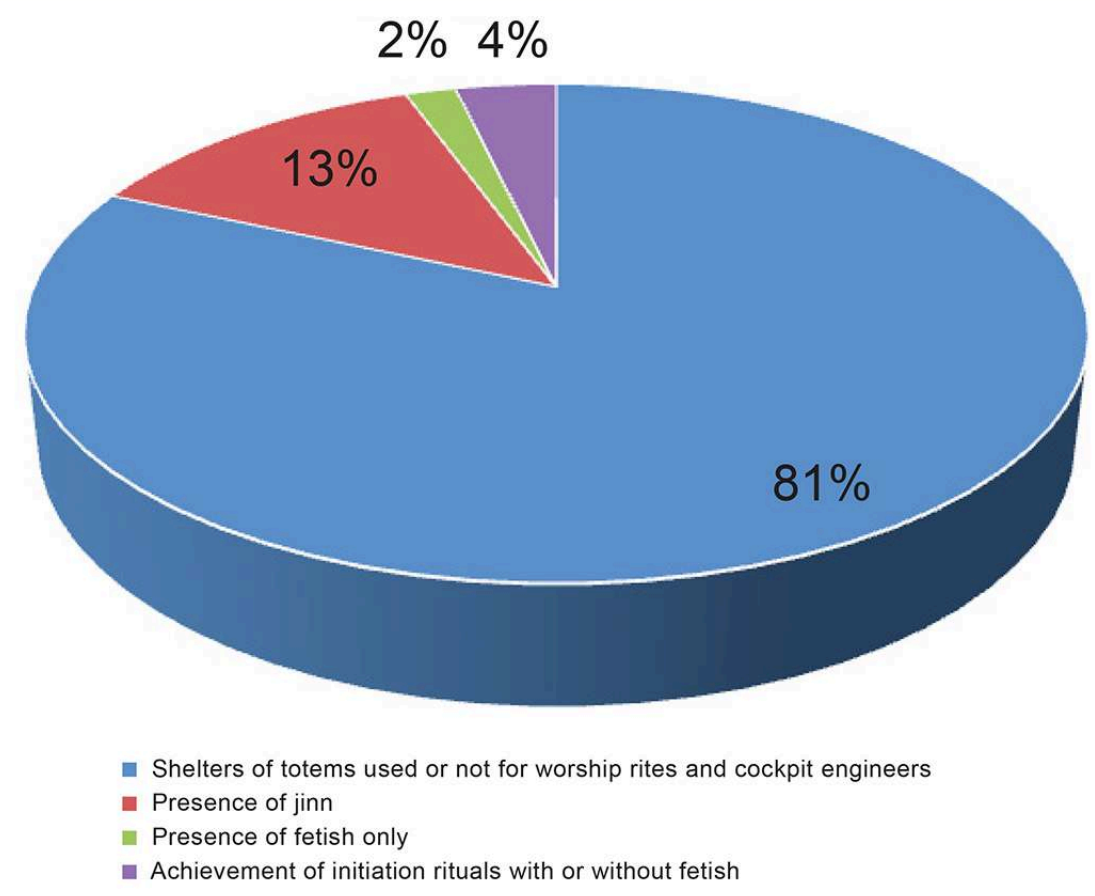

Source: Surveys, 2015

The importance of the number of sites used as shelters for totems lies in the fact that the Joola believes that each human being is doubled by an animal with which he is bound by a destiny and a common conscience (Journet-Diallo 1998). To be honest, this custom, which withstands the ravages of time, reveals the important place occupied by the animal world in traditional society. In Senegal as in many parts of the world, we find this type of consideration vis-à-vis the animal world. In the Serer Ndut and Lebous 
of Senegal, it is forbidden to kill the totem because it is the incarnation of the ancestor or genius (Dupire 1991, Dumez \& Ka 2000, Diouf 2011). For example in Kaolack, the monitor lizard is highly respected. Indeed, the tutelary genius of the city known as Mbossé is manifested in the form of this animal. This status gives it a sacred character that makes rites and offerings are made in his honor. People are forbidden to hurt him even less to kill him. According to Chretien \& Triaud (1999), "if they are accidentally hit or injured, they can become crippled, or the body may become covered with scales. One falls into a crisis of madness, one spits blood, and death occurs if, quickly, the priestess does not make the appropriate rites to purify the delinquent. If finally the monitor is killed, no one can save the person responsible for the bite of the snake, double the peaceful little saurian. Of course, it is also forbidden to eat the monitor at Kaolack". Many African populations in Guinea Bissau, Côte d'Ivoire, Burkina Faso, Togo, etc., also maintain such practices (Butare 2003). Outside the African continent, especially in Vanuatu (an archipelago located in the South Western Pacific), certain species of fish, octopus, giant clams, turtles, sharks or moray eels, or terrestrial species are totems and banned from consumption by respect to ancestors for many cultural groups (Hickey 2007). Among Amerindians also the ingestion of the animal-totem is part of the fundamental prohibitions of this people (Durand-Rous 2017). In Vietnam especially in the coastal villages of the center and the south the sanctity of cetaceans removes any possibility of their being exploited (Robineau 1998).

In sacred natural sites, specific species of fish, mammals, reptiles, birds and crustaceans are protected, and their capture is prohibited. A system of taboos and rules governs the sites. The exploitation of the resources is forbidden, but if it is allowed, only a category of people is authorized to take samples there. They may be insiders, customary chiefs or custodial family members. The transgression of forbidden introduces a stain on the individual that can extend to all the lineage if the fault is not repaired. Durand-Rous (2017) underlines this fact with regard to the taboo surrounding totem poles among Native Americans. The author writes that the transgression of interdicts leads to a defilement on the individual and the mark of the seal of impurity which can spread to the whole clan by contagion.

Some popular beliefs such as the existence of supernatural beings in the marine environment or in the forest have also played a key role in conservation. It is believed that some of these creatures do not hesitate to annihilate anyone daring to venture there. For many species of fish, these places serve as refuge and reproduction (Gadou 2003). Thus, thanks to these beliefs, the mangrove as well as a significant part of its biodiversity have been preserved.

Spaces declared sacred represent values that go beyond a simple conservation action. In the study area almost all the sacred natural sites encountered are still well maintained by the local populations. Traditional rules, based on local knowledge passed down through the generations ensure their conservation. Nevertheless, there are some sites whose respect is no longer tenacious. Moreover, many are now desecrated since the adoption of Islam and Christianity, the modernization of the Joola society, etc. (Diatta et al. 2017). It should be noted that the adoption of so-called revealed religions, namely, Islam and Christianity, has weakened Joola society and favored the erosion of many rites. This change is on the one hand perceived in the behaviors of the converts and on the other hand on the practices. In addition, these two great religions favored 
the rejection and abandonment of the customs associated with animist worship and at the same time contributed to the erosion of traditional practices.

\section{The Joola knowledge and practices: an important contribution to mangrove management in Lower Casamance}

In Lower Casamance, the Joola populations have developed in their perceptions, a series of knowledge and practices that have contributed to the conservation of the mangrove forests. For these populations, the mangrove is perceived as the place of expression of cultural identity. Hoffmann (2002) reports the same perception among Black communities in Pacific Colombia. Moreover, many of its resources have significant symbolic value for both Joola and many Senegalese populations (Dupire 1991, Dumez \& Ka 2000, Cisse et al. 2004) in Africa (Butare 2003, Cormier-Salem et al. 2002, Oyono et al. 2012) and elsewhere (Robineau 1998, Hickey 2007).

For populations that depend upon mangrove forests, molluscs are one of the main sources of animal protein. Totemic species in some (Joola populations of Lower Casamance) and essential elements for the realization of certain rites in others (Bijagos populations of Guinea Bissau), molluscs are of great cultural importance. For the Bijagos peoples, Crassostrea gasar and Tagelus adansonii are of great traditional importance and are used during the Defunto women's initiation ceremony (Ka et al. s.d.). In the Coral Triangle region of the western Pacific Ocean, Aswani (2012) reports that many coastal communities still practice customary management. For this author, despite the influence of external factors, including economic and socio-cultural modernization, local populations in the Coral Triangle region have been able to maintain these customary management systems, which "are based on ancestral practices of regulation of the use of coral reefs, access and transfer of resources at the local level. Moreover, according to Diallo (Cissé et al. 2004) "if what we call today respect for the environment and the sustainable management of natural resources has equivalent cases in so-called traditional cultures and societies [...] because the latter were based on a conception, rules and values that implied or even enacted a harmonious or balanced relationship with nature [...]". In this regard, UICN/CEESP (2010) demonstrate that for many indigenous peoples in the Amazon and Europe, "knowledge and respect for customary rules" physically allow soil, water and life to regenerate by linking the past, the present and future (UICN/CEESP 2010).

The prohibitions that dictate behaviors and attitudes towards these taboo mangrove areas have fostered the development of knowledge of great ecological importance. For example, thanks to close contact with the natural environment, fishermen in particular can obtain a substantial knowledge of the ecology of marine animals. As is the case with Moken fishers from Thailand (Arunotai 2006), or indigenous peoples of Papua New Guinea, Solomon Islands and Vanuatu (Hviding 2006), Joola fishermen have a good knowledge of marine animals, their characteristics, habitats, breeding areas, etc. Thus, like the traditional practices of many indigenous peoples, Joola practices are an important means of securing resources. Taboos, prohibitive, totemism are remarkable ecological practices in which relevant ecological knowledge is expressed (Artaud 2014, Tahirindraza 2015). Cependant, bien qu'étant bénéfique pour les ressources naturelles, à l'origine l'objectif de ces pratiques était tout autre (Dugast 2002) 


\section{Threats to local mangrove resource management systems} significant contributions to the conservation of biodiversity in general and mangroves in particular. The conservation of the mangrove ecosystem is also supported by through temporal restrictions on the harvest of shellfish: oyster / Crassostrea gasar and ark / Anadara senilis. These traditional practices have not been valued by contemporary decision-makers or conservationists (NGOs, foundations, etc.) as a means of strengthening the management of the natural resources, even though traditional practices and designations clearly promote mangrove conservation. Faced with the consequences of modernization, education, the imposition of other cultures and the strong preponderance of the monotheistic religions, the perpetuation of these practices by traditional societies is currently threatened. This significant decline in traditional practices has had a major impact on the mangrove ecosystem and on natural resources in general.

Thus, while local customs and beliefs favor the rational management of mangrove ecosystems, current practices contribute to their destruction, such as unsustainable fishing techniques and the cutting of mangrove forests. These changes are due to the gradual replacement of traditional practices with a market economy in these regions in Senegal, which is pushing local populations to overexploit natural resources. Man is no 
longer content to take the resource for sustenance, but instead is concerned with maximizing immediate profit. Nevertheless, there are still opportunities today to foster and protect and, above all, rehabilitate endogenous knowledge and practices for the sustainable management of biological diversity. This is how the ICCAs (Indigenous and Community Heritage Area) favor management schemes and management choices based on respect for local natural and cultural heritage.

The authors warmly thank the scientific committee of the 6th edition of the Casamansun International Symposium and their partners. These thanks also go to the local people for their collaboration, to the customary and administrative authorities, as well as to all the people who directly or indirectly helped to write this article.

\section{BIBLIOGRAPHY}

ANSD (Agence Nationale de la Statistique et de la Démographie) 2015 - Situation économique et sociale régionale 2013. Service Régional de la Statistique et de la Démographie de Ziguinchor, $126 \mathrm{p}$. Arunotai N. 2006 - Les savoirs traditionnels des Moken : une forme non reconnue de gestion et de préservation des ressources naturelles. Revue internationale des sciences sociales $187: 145-158$. [En ligne :] http://www.cairn.info/revue-internationale-des-sciences-sociales-2006-1-page-145.htm ; DOI : $10.3917 /$ riss. 187.0145

Artaud H. 2014 - De l'« efficacité » symbolique des interdits à leur fonctionnalité écologique. Revue d'ethnoécologie, 6 | 2014. [En ligne :] http://ethnoecologie.revues.org/2055 ; DOI : 10.4000/ ethnoecologie.2055

Aswani S. 2012 - Gestion hybride coutumière et écosystémique pour la conservation des ressources marines dans le Triangle de corail. Ressources marines et traditions. Bulletin d'information de la CPS 28 : 14-35. [En ligne :] http://www.spc.int/DigitalLibrary/Doc/FAME/ InfoBull/TRAD_VF/28/Trad28VF_14_Aswani.pdf

Badiane S.D. 2012 - Espaces forestiers de la Casamance amphibie (Sénégal). Déterminisme territorial, biodiversité et stratégies de conservation. Thèse de doctorat unique, Environnement littoral, UCAD/Dakar, 320 p.

Badji S. 2015 - Contribution à l'étude des mollusques exploités dans l'AMP d'Abéné et dans les îles de la commune de Kafountine (Boune et Boko). Mémoire de Master 2, Gestion des Écosystèmes Aquatiques. IUPA/UCAD, $61 \mathrm{p}$.

Bassene O.A. 2016- L'évolution des mangroves de la Basse Casamance au sud du Sénégal au cours des 60 dernières années : surexploitation des ressources, pression urbaine, et tentatives de mise en place d'une gestion durable. Thèse de Doctorat unique, Géographie, Université de Lyon/Université Jean Monnet de Saint-Etienne, France/Université Gaston Berger de Saint-Louis, Sénégal, 310 p. Bodian D.M. 2018 - Enjeux de pouvoirs et rapports au pays d'origine dans les associations d'immigrés diolas en France. Thèse de doctorat, Sociologie, Université de Grenoble Alpes/École Doctorale Sciences de l'homme, du Politique et du Territoire, $382 \mathrm{p}$. 
Borrini-Feyerabend G., Chatelain C. \& Tous P. 2009 - Rapport pour l'Association des Pêcheurs de la Communauté Rurale de Mangagoulack. CENESTA, le PNUD/FEM/SGP et la FIBA, 79 p.

Butare I. 2003 - Pratiques culturelles et conservation de la biodiversité en Afrique de l'Ouest et du centre. Actes du Séminaire-Atelier de Ouagadougou (Burkina Faso) du 18 au 21 juin 2001. IDRC/CRDI. Zoom Edition, $251 \mathrm{p}$.

Chrétien J.-P. \& Triaud J.-L. 1999 - Histoire d'Afrique, les enjeux de mémoire. Paris, Karthala, 503 p.

Cisse A.T., Ghysel A. \& Vermeulen C. 2004 - Systèmes de croyances Niominka et gestion des ressources naturelles de mangrove. International Symposium, Tropical Forests in a Changing Global Context, Royal Academy of Overseas Sciences. United Nations Educational, Scientific and Cultural Organization Brussels, 8-9 November, $2004:$ 207-332.

Cormier-Salem M.-C.- 1992 - Gestion et évolution des espaces aquatiques, La Casamance. Paris, ORSTOM, 571 p. (Études et thèses).

Cormier-Salem M.-C. 1999 - Rivière du Sud: Société et mangrove ouest africaines. Paris, IRD. 2 vol.

Cormier-Salem M.-C., Juhé-Beaulaton D., Boutrais J. \& Roussel B. 2002 - Patrimonialiser la nature tropicale. Dynamiques locales et enjeux internationaux. Paris, IRD, $467 \mathrm{p}$.

Cormier-Salem M.-C., Sané T. \& Dieye E.H.B. 2015 - Légitimité des politiques de reboisement des palétuviers en Casamance. In : Descroix L., Djiba S., Sané T., Tarchiani V. (Ed.) Eaux et sociétés face au changement climatique dans le bassin de la Casamance : actes de l'Atelier scientifique et du lancement de l'initiative "Casamance : un réseau scientifique au service du développement en Casamance". Paris, L'Harmattan : 189-210. [En ligne :] https://pdfs.semanticscholar.org/ 4fe1/01dfe1e0cf6978f37a2968a581db9a9e1d48.pdf.

Diatta C.S. 2012 - Le rôle des sites naturels sacrés pour la conservation des ressources naturelles marines et côtières : l'exemple du Petit Kassa et de l'aire du patrimoine autochtone et communautaire de Mangagoulack (Casamance). Mémoire de Master : Gestion des Ecosystèmes Aquatiques, Institut Universitaire des Pêches et d'Aquaculture (IUPA), UCAD, $87 \mathrm{p}$.

Diatta C.S. 2018 - Savoirs locaux et modes traditionnels de gestion des ressources naturelles marines et côtières en Basse-Casamance : perspectives de leur intégration dans le système conventionnel. Thèse de doctorat unique, Géographie, option Environnement. UCAD/Dakar, 315 p.

Diatta C.S., Diouf M., Karibuhoye C. \& Sow A.A. 2017 - Sites naturels sacrés et conservation des ressources marines et côtières en milieu traditionnel diola (Sénégal). Revue d'ethnoécologie 11. [En ligne :] http://ethnoecologie.revues.org/2900

Diedhiou L. 2001 - Projets de développement et représentations sociales en Basse Casamance : Le DERBAC et le PROGES. Thèse de Doctorat, sociologie. Faculté des arts et sciences, Université de Montréal, $399 \mathrm{p}$.

Diedhiou P. 2011 - L'identité Jóola en question (Casamance). La bataille idéologique du MFDC pour l'indépendance. Paris, Karthala, $404 \mathrm{p}$.

Dioh B.C. 1976 - L'ostréiculture au Sénégal. Thèse de doctorat d'état, Sciences et Médecine Vétérinaire, 107 pages

Diouf I. 2011 - Croyances et pratiques magico-religieuses traditionnelles à Rome et en milieu sérère : étude comparative. Thèse de doctorat unique, Histoire/Sciences de l'Antiquité. UCAD Dakar, 409 p.

Dugast S. 2002 - Modes d'appréhension de la nature et gestion patrimoniale du milieu. In : Cormier-Salem M.-C., Juhé-Beaulaton D., Boutrais J.B. \& Roussel B., Patrimonialiser la nature tropicale : dynamiques locales, enjeux internationaux. Paris, IRD : 31-78. 
Dumez R. \& Ka M. 2000 - Territoire assiégé yoff. Un village lébou dans la banlieue de Dakar. Programme Environnement Université Cheikh Anta Diop de Dakar - Chaire UNESCO Ed. UNESCO.CNRS, 81 p. (Dossiers régions côtières et petites îles ; 7). [En ligne] http://www.unesco.org/csi/pub/papers2/ yoff.htm

Dupire M. 1991 - Totems sereer et contrôle rituel de l'environnement. L'Homme 31 (118) : 37-66. [En ligne :] http://www.persee.fr/doc/hom_0439-4216_1991_num_31_118_369379

Durand-Rous C. 2017 - Le totem réinventé. Exploration de l'identité et redéfinition de soi dans la fiction amérindienne contemporaine. Thèse de Doctorat, 481 p. [En ligne :] www.theses.fr/ 2017PERP0043.pdf

FAO 1995 - Approche participative, communication et gestion des ressources forestières en Afrique sahélienne : Bilan et perspectives. Rome, FAO. [En ligne :] http://www.fao.org/3/v9974f/ v9974f00.htm

FAO 2007 - The world's mangrove 1980-2005. Rome, FAO, 89 p. (FAO forestry paper ; 153).

Gadou D.M. 2003 - Préservation de la biodiversité, les réponses des religions africaines. In : Butare I. Pratiques culturelles et conservation de la biodiversité en Afrique de l'Ouest et du centre. Actes $d u$ Séminaire-Atelier de Ouagadougou (Burkina Faso) du 18 au 21 juin 2001 : 46-67.

HARZA 1984 - Plan directeur de développement agricole en Basse Casamance. Rapport final, 2 T., 354-302 p.

Hickey F.R. 2007 - Gestion traditionnelle des ressources marines à Vanuatu : reconnaître, appuyer et renforcer les systèmes autochtones de gestion des ressources. Ressources marines et traditions. Bulletin de la CPS, $20: 11-23$. [En ligne :] http://www.spc.int/DigitalLibrary/Doc/FAME/ InfoBull/TRAD_VF/20/TRAD20VF_11_Hickey.pdf

Hoffmann 0. 2002 - L'émergence de la notion de patrimoine dans le cadre de revendications identitaires et territoriales (Pacifique colombien). In : Cormier-Salem M.-C., Juhé-Beaulaton D., Boutrais J.B. \& Roussel B., Patrimonialiser la nature tropicale : dynamiques locales, enjeux internationaux. Paris, IRD : 191-214.

Hviding E. 2006 - Connaître et gérer la biodiversité dans les îles du Pacifique : problèmes posés par la préservation du lagon de Marovo. Revue internationale des sciences sociales 1 (187) : 73-90. DOI : 10.3917/riss.187.0073. [En ligne :] http://www.cairn.info/revue-internationale-des-sciencessociales-2006-1-page-73.htm

IMAO (Initiative Mangrove en Afrique de l'Ouest) 2009 - Rapport annuel sur les mangroves du Sénégal. Dakar, UICN, 65 p.

Journet-Diallo 0. 1998 - Un monde diffracté. Théories joola du double animal. Systèmes de pensée en Afrique noire, 15 |, 203-230. [En ligne] : Https://span.revues.org/1598 HTML, consulté le 15 février 2015.

Journet-Diallo O. 2007 - Les Créances de la Terre : chroniques du pays Jamaat (Joola de Guinée Bissau). Turnhout, Brepols. (Collection de l'École Pratique des Hautes Études ; 134).

Juhé-Beaulaton D. \& Roussel B. 2002 - Les sites religieux vodun. Des patrimoines en permanente évolution. In : Cormier-Salem M.-C., Juhé-Beaulaton D., Boutrais J.B. \& Roussel B., Patrimonialiser la nature tropicale : dynamiques locales, enjeux internationaux. Paris, IRD : 415-438.

Juhé-Beaulaton D. 2010 - Forêts sacrées et sanctuaires boisés. Des créations culturelles et biologiques (Burkina Faso, Togo, Bénin). Paris, Karthala, 280 p. 
KA S., Sarr O., Bernatets C. \& Cormier-Salem M.-C. n.d. - Pratiques locales de gestion des ressources dans les mangroves ouest-africaines et impacts : cas des coquillages. Colloque IRD, UMR208, Patrimoines Locaux, IRD/MNHN. [En ligne :] http://localiserlesproduits.mnhn.fr/ 19_Paper_KA_S.pdf

Laffargue C. 2010 - Bilan écologique \& proposition de suivi participatif de la biodiversité dans l'Aire du Patrimoine Autochtone et Communautaire de KAWAWANA et dans la Communauté Rurale de Mangagoulack. APCRM / FIBA, 80 p.

Marius C. 1985 - Mangroves du Sénégal et de Gambie (Écologie, Pédologie, Géochimie, Mise en valeur et aménagement). Paris, ORSTOM, 357 p. (Travaux et Documents ; 193).

Marut J.C. 2010 - Le conflit de Casamance : ce que disent les armes. Paris, Karthala, 420 p.

Marzouk-Schmitz Y. 1993 - Du côté de la Casamance : pouvoirs, espaces et religions. Cahiers d'études africaines 33 (131) : 483-491. doi : 10.3406/cea.1993.1513. [En ligne :] http:// www.persee.fr/doc/cea_0008-0055_1993_num_33_131_1513

Oyono P.R., Fall S.M., Karibuhoye C.S., Said A.R., Sidibeh L. \& Sow M. 2012 - Les sites naturels sacrés de l'écorégion côtière et marine ouest-africaine. Une exploration et des options de reconnaissance institutionnelle. Dakar, FIBA, 49 p.

Pélissier P. 1966 - Les paysans du Sénégal. Les civilisations agraires du Cayor à la Casamance. St Yrieix, Fabrègue, $939 \mathrm{p}$.

Robineau D. 1998 - Contribution des temples dédiés aux cétacés à l'inventaire de la biodiversité (Vietnam). In : UNESCO-CNRS-MNHN Natural sacred sites, cultural diversity and Biological diversity.

Sagna P. 2007 - Caractéristiques climatiques. Atlas du Sénégal. 1re éd. Paris, Jeune Afrique, Jaguar France : $66-69$

Seck A.A. 1986 - L'exploitation des mollusques dans le cadre d'un aménagement de la mangrove sénégalaise : le cas des huitres et des arches. Mémoire de DEA, Sciences de l'Environnement, Université de Dakar, 122 p.

Sene C., Dioh P. \& Mormont M. 2013- Pratiques traditionnelles et gestion durable des ressources naturelles : étude de cas des sites naturels sacrés côtiers et marins à Jaol-Fadiouth. ASRDLF : 1-18

Solly B., Dièye E.H.B., Sané T. \& Diaw A.T. 2018 - Dynamique de la Mangrove de Thiobon dans l'estuaire de la Casamance (Sénégal) entre 1972 et 2017. European Scientific Journal 14 (33) : 118-133. Doi: 10.19044/esj.2018.v14n33p118. [En ligne :] http://dx.doi.org/10.19044/esj. 2018.v14n33p118

Tahirindraza H. 2015 - Les tabous au service de la conservation durable de l'espace Tanalana, sud-ouest de Madagascar. Recherche participative pour le soutien de gestion durable des terres au Plateau Mahafaly au sud-ouest du Madagascar. Sustainable Land Management in Madagascar (SuLaMa). [En ligne :] www.sulama.de/files/products/WP5_produit1_Tabous_fr.pdf.

Thomas L.V. 1958-1959 - Les Diola : essais d'analyse fonctionnelle sur une population de Basse Casamance. Dakar, IFAN, 2 t., 343 et 821 p.

Trincaz P.X. 1981 - Colonisation et Régionalisme, Ziguinchor en Casamance. ORSTOM, 271 p.

UICN/CEESP 102010 - La diversité bio-culturelle conservée par les peuples autochtones et les communautés locales. Exemples et analyses. 71 p. [En ligne :] https://www.iucn.org/fr/content/ladiversite-bio-culturelle-conservee-par-les-peuples-autochtones-et-les-communautes-localesexemples-et-analyses 
Vieillefon J. 1975 - Notice explicative de la carte pédologique de la Basse Casamance. Paris, ORSTOM, $59 \mathrm{p}$.

Wild R. \& Mcleod C. 2008 - Sites naturels sacrés : Lignes directrices pour les gestionnaires d'aires protégées. Gland, Suisse, UICN ,131 p.

\section{ABSTRACTS}

The mangrove ecosystem is one of the most productive in Casamance and the most important biomes in Senegal. This threatened ecosystem is found on the banks of Casamance river and along its tributaries, known as the bolong or inlets. The importance of the mangrove ecosystem results from its biodiversity and its ecological, economic and socio-cultural in particular functions ritual places, totem cockpit, etc. The Lower Casamance mangroves are the site of diverse traditional representations and activities of the Joola society, including prohibitions on the cutting of mangroves and seasonal restrictions on the harvesting of oysters in restricted access. We conducted research designed to understand the practices associated with the use of mangroves by the Joola society. The methodology we used is a combination of qualitative and quantitative approaches. Semi-structured informal and individual interviews, as well as field observations were carried out. The results of our research show that mangroves are considered sacred by the Joola and that the practices they conduct in these areas are governed by very strict and traditional rules. These practices are animated by various representations that crystallize their behaviors in totems, taboos, rituals and the sacredness of natural spaces. However, with the adoption of monotheistic religions notably Islam and Christianity, certain prohibitions and beliefs that have preserved these spaces are disappearing and that mangroves are deteriorating. Therefore, traditional methods of in situ conservation must be preserved in order to ensure the protection of mangrove ecosystems. This article highlights the importance of Joola customs and practices and reviews traditional methods that have favored the conservation of parts of the mangrove.

La mangrove constitue un des écosystèmes les plus productifs de la Casamance et une biomasse des plus importantes au Sénégal. Cet écosystème fragile et menacé se trouve sur les rives du fleuve Casamance (principal cours d'eau de la région) et de ses affluents les bolongs. L'importance de cette formation découle de sa biodiversité et de ses fonctions écologiques, économiques et socioculturelles notamment de lieux de rituel, habitacle de totem, etc.

En Basse Casamance, la mangrove est le théâtre de diverses représentations et activités traditionnelles de la société diola. Elle est associée à des croyances qui interdisent de couper le bois de mangrove et de collecter des huîtres durant l'hivernage. L'accès aux zones de mangrove réservées aux pratiques culturelles (initiation) ou cultuelles (rituelles) est limité voire interdit. La méthodologie que nous avons utilisée est une combinaison d'approches qualitatives et quantitatives. Des entretiens semi-structurés informels et individuels, ainsi que des observations sur le terrain ont également été réalisés. Les résultats de nos recherches montrent que les espaces de mangrove associée aux pratiques traditionnelles sont déclarés sacrés et régis par des règles très strictes et traditionnelles. Ces pratiques sont animées par diverses représentations qui cristallisent leurs comportements dans des totems, des tabous, des rituels et le caractère sacré des espaces naturels. Cependant, avec l'adoption des religions monothéistes notamment l'islam et le christianisme, certaines interdictions et croyances qui ont préservé ces espaces disparaissent et les mangroves se dégradent. Pourtant, ces espaces de mangrove sacrée font partis des sites les moins soumis aux phénomènes de dégradation. Par conséquent, les méthodes traditionnelles de conservation in situ doivent être préservées afin d'assurer la protection des écosystèmes de mangroves. Cet article met en évidence l'importance des coutumes et pratiques 
diola et passe en revue les méthodes traditionnelles qui ont favorisé la conservation de certaines parties de la mangrove.

\section{INDEX}

Mots-clés: civilisation diola, gestion, mangrove, Basse Casamance

Keywords: joola civilization, management, mangrove, Lower Casamance

\section{AUTHORS}

\section{CLAUDETTE SOUMBANE DIATTA}

Department of Geography, University Cheikh Anta Diop of Dakar (UCAD), Senegal, claudettediatta@gmail.com

\section{MALICK DIOUF}

Department of Animal Biology / Sciences of Technologies Faculty, Institute of Fisheries and Aquaculture (IUPA) / University Cheikh Anta Diop of Dakar (UCAD), Senegal

\section{AMADOU ABDOUL SOW}

Department of Geography / Faculty of Human Letters and Sciences, University Cheikh Anta Diop of Dakar (UCAD), Senegal, amadouabdoul.sow@ucad.edu.sn

\section{CHARLOTTE KARIBUHOYE}

$\mathrm{PhD}$, Director, West Africa program MAVA Foundation 